\title{
Adatok Somogy megye kisemlős faunájának ismeretéhez, gyöngybagoly Tyto alba (ScOPOLI, 1769) köpetek vizsgálata alapján
}

\author{
PURGER J. JENŐ \\ Pécsi Tudományegyetem, Természettudományi Kar, Biológiai Intézet, Ökológiai Tanszék, H-7624 Pécs, Ifjúság útja 6. , \\ e-mail: purger@gamma.ttk.pte.hu
}

PURGer J. J.: Data to the knowledge of small mammal fauna of Somogy county (Hungary), based on Barn Owl Tyto alba (Scopoli, 1769) pellet analysis.

Abstract: Pellets were collected between 1995 and 2016, from 53 localities (investigated area: XL89, XL99, YL08, YL09, XM52, XM61, XM62, XM70, XM72, XM74, XM80, XM81, XM82, XM83, XM84, XM90, XM91, XM93, XM95, YM02, YM03, YM12, YM13, YM14, YM22, YM23, YM24 and BS73, according to $10 \times 10 \mathrm{~km}$ UTM grids). In a total of 5164 Barn Owl pellets 14360 prey remnants were found. In the diet of Barn Owls small mammals dominated (98.6\%). From the prey items the presence of 27 mammal species (Crocidura leucodon, C. suaveolens, Sorex araneus, S. minutus, Neomys anomalus, N. fodiens, Talpa europaea, Eptesicus serotinus, Nyctalus leisleri, N. noctula, Myotis myotis, Muscardinus avellanarius, Microtus agrestis, M. arvalis, $M$. subterraneus, Arvicola amphibius, Myodes glareolus, Apodemus agrarius, A. flavicollis, A. sylvaticus, A. uralensis, Micromys minutus, Mus musculus, M. spicilegus, Rattus norvegicus, $R$. rattus, Mustela nivalis) was confirmed. Remnants of birds, amphibians and insects made up only $1.4 \%$ of total prey.

Keywords: diet, distribution, Soricomorpha, Chiroptera, Rodentia, Weasel

\section{Bevezetés}

Somogy megye emlősfaunájáról gazdag ismeretanyaggal rendelkezünk, amihez nagyban hozzájárultak a megye területén mintegy két és fél évtizede folyó szisztematikus kisemlős felmérések eredményei (LANSZKI \& PURGER 2001, BIHARI et al. 2007). Ezek a felmérések részben indirekt módon, gyöngybagoly (Tyto alba) köpetek begyűjtésével és vizsgálatával történtek. A gyöngybaglyok elsősorban kisemlősöket (<200 g) zsákmányolnak (BunN et al. 1982, GonZÁLEZ-FISCHER et al. 2011), az elfogyasztott állatok emészthetetlen részeit, hosszúkás gombóc alakú köpetek formájában visszaöklendezik költő és pihenőhelyeiken (MıKKOLA 1983, MÄRz 2011). A köpetek szétszedése során előkerülő csontmaradványok alapján meghatározott kisemlősök faj- és egyedszám összetételéből következtethetünk a gyöngybaglyok vadászterületeinek kisemlős faunájára (TAYLOR 1994), így e módszer segítségével rengeteg adat gyűjthető. A felmérések Somogy megye teljes területére kiterjedtek és az eddig feldolgozott, több mint 22 ezer köpetböl kimutatott kisemlösök egyedszáma meghaladta a 65 ezret (PuRger 1996, 1997, 1998, 2002, 2004, 2005, 2008, 2013, 2014a, 2014b). A munkát akár befejezettnek is tekinthetnénk, de a Gyöngybagolyvédelmi Alapítvány felajánlotta a korábban gyűjtött köpetmintáit és időközben néhány lelöhelyröl újabb mintákat is begyűjtöttünk.
Abban a reményben, hogy Somogy megye kisemlős faunájának ismereteit további adatokkal gazdagítsuk, célunk az volt, hogy a begyűjtött több mint 5000 gyöngybagoly köpetet feldolgozzuk, és az eredményeket közzétegyük.

\section{Anyag és módszerek}

A faunisztikai (biotikai) adatok összevethetőségének lehetősége érdekében (DÉVAl et al. 1997), Somogy megyében korábban a bagolyköpet gyüjtések, azaz a kisemlős fauna felmérések $10 \times 10 \mathrm{~km}$-es UTM rendszerü hálótérképek alapján (MıskoLCzı et al. 1997), az egyes négyzeteknek megfelelő területeken folytak. Így a jelen dolgozatban bemutatott eredmények is e rendszert követik. A köpetek zöme másfél évtizeddel ezelőtti gyűjtések eredménye, de van néhány korábbi és néhány egészen új mintánk is. Összesen 28 UTM négyzet (XL89, XL99, YL08, YL09, XM52, XM61, XM62, XM70, XM72, XM74, XM80, XM81, XM82, XM83, XM84, XM90, XM91, XM93, XM95, YM02, YM03, YM12, YM13, YM14, YM22, YM23, YM24, BS73) által lefedett területen (1. ábra), 53 lelöhelyen folytak gyűjtések (1a-i. táblázat). Egyes lelőhelyekről több minta is származik, így összesen 106 minta, azaz 5164 köpet lett feldolgozva (1a-i. táblázat). A vizsgált terület bejárását, valamint a köpetek gyüjtését Fenyősi László (FL), Horváth Zoltán (HZ), Mezei Ervin (ME), Pintér András (PA), Purger J. Jenő (PJJ), Sipter Csanád (SCs) és a Gyöngybagolyvédelmi Alapítvány (GyA) munkatársai végezték (1a-i. táblázat). Néhány esetben a lelőhelyek precíz megnevezése gondot okozott, mint pl. Csokonyavisonta esetében. Ez a település Erdőcsokonya (délen) és Somogyvisonta (északon) egyesítésével jött létre, így két református (ref. temp.) és római katolikus (kat. temp.) temploma van. Annak érdekében, hogy pontosan feltüntessük, hogy melyik templomból származik a mintánk, a helységnév "Csokonya”, vagy "-visonta" részét aláhúztuk (1c., 1d. táblázat). Csokonyavisonta és Szulok között van Békepuszta (vagy Béke-puszta), de sokszor Alexandra-puszta néven emlegetik (pl. BALOGH et al. 1974). A táblázatunkban (1e. táblázat) azonban a Békepuszta elnevezés szerepel, mivel korábban is ezt a nevet használtuk (PURGER 1997).

A begyűjtött köpetek szétszedése során elökerülő koponyák, állkapcsok, fogak alapján az egyes emlősfajok egyedei jól elkülöníthetők egymástól, így a köpetvizsgálatok a kisemlös fauna felmérések egyik leghatékonyabb módszere (SCHMIDT 1967, MIKUSKA et al. 1979). A munka során csak az egész köpetek let- 


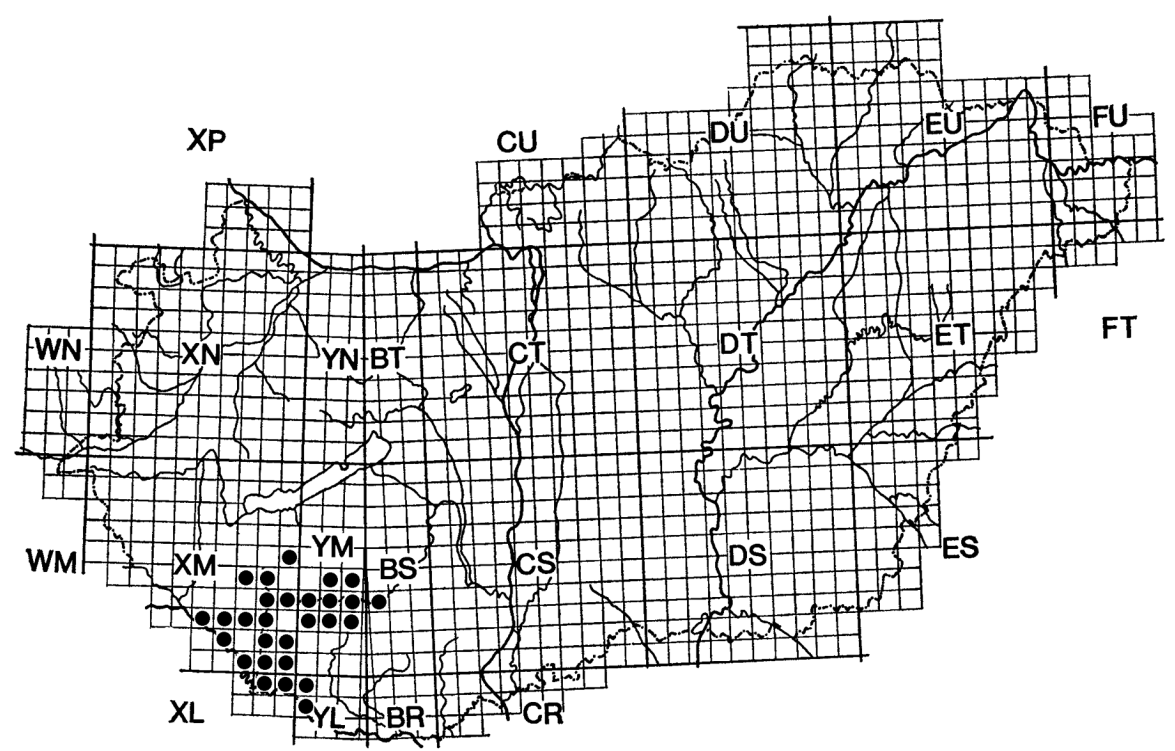

1. ábra. A vizsgált terület elhelyezkedése Magyarország UTM rendszerü hálótérképén.

Figure 1. Situation of the investigated area in the UTM grid map of Hungary.

tek feldolgozva. A minták többségében a köpetek korát nem lehetett megbecsülni, így a dátumok csak a gyüjtés idejét jelzik (1a-i. táblázat). Amennyiben egy helyszínen több alkalommal is folyt gyüjtés, beazonosítható, hogy az egyes köpetek milyen időközökböl származnak. A köpeteket szétbontását elszívófülke alatt száraz technikával, azaz kézzel, csipesszel és fogkefével végeztük (SCHMIDT 1967, MIKUSKA et al. 1979). $A z$ egyes köpetekből előkerült kisemlősök egyedszámát a koponyák- és az azokhoz tartozó állkapcsok száma alapján adtuk meg. Amennyiben egy köpetböl csak egy vagy két állkapocs került elő, de a koponya nem, akkor ezeket nem vettük figyelembe az egyedszám megadásánál. A kisemlősök meghatározása csonttani bélyegek alapján történt (Ács 1985, KRYŠTUFEK 1985, 1991, KRYŠTUFEK \& JANŽEKOVIČ 1999, MÄRZ 2011, NiETHAMMER \& KRAPP 1978, 1982, 1990, SCHMIDT 1967, UJHELYI 1989, ZÖRÉNYI 1990, YALDEN 1977, YALDEN \& MoRRIS 1990). A Sylvaemus szubgénuszba tartozó fajok meghatározásánál TVRTKOVIĆ (1979) módszerét követtük. A Neomys génuszba tartozó két faj, a közönséges vízicickány (Neomys fodiens) és a Miller-vízicickány (Neomys anomalus) meghatározását TVRTKović et al. (1980) által leírt módon végeztük. A házi egér (Mus musculus) és güzüegér (Mus spicilegus) elkülönítésénél MACHOLÁN (1996) határozókulcsát használtuk. Az Apodemus, Mus és Rattus génuszba tartozó, nehezen határozható vagy sérült példányok, mint Apodemus sp., Mus sp. és Rattus sp. kerültek a fajlistákra (1a-i., 2a-c. táblázat). Az emlősfajok tudományos és magyar neveit BIHARI et al. (2007) munkája alapján használtuk.

\section{Eredmények és értékelés}

Somogy megye 28 10×10 km-es UTM négyzet által lefedett területéről begyüjtött 5164 gyöngybagoly köpetből 14360 zsákmányállat maradványai kerültek elő (1a-i. táblázat). Ebböl következik, hogy egy köpet átlagosan
2,8 zsákmány maradványait tartalmazta. A területen élő gyöngybaglyok táplálékában a kisemlősök domináltak $(98,6 \%)$. A zsákmány mindössze 1,4\%-át alkották madarak, kétéltűek és rovarok (1a-i. táblázat).

A szétbontott köpetekből 27 kisemlős faj 14154 egyedének maradványai kerültek elő (2a-c. táblázat).

A gyöngybaglyok táplálékának mintegy $42,3 \%$-át a cickányalakúak rendjébe (Soricomorpha) tartozó fajok egyedei alkották. A köpetekből kimutatott 6 cickányfaj közül eredményeink 3 faj elterjedésének pontosításához járultak hozzá. A törpe cickány (Sorex minutus) előfordulását az XM70-es UTM négyzet területén a korábbi vizsgálatok során (PURGER 1998) valószínű, hogy a kis mintaszám miatt nem sikerült bizonyítanunk, de most a bolhói és vízvári mintákból több példány maradványai is előkerültek (1c., 2a. táblázat). A törpe cickányhoz hasonlóan az XM70-es UTM négyzet területén a Miller-vízicikány (Neomys anomalus) jelenlétét sem sikerült korábban bizonyítanunk (PURGER 1998), de a Bolhón gyűjtött köpetekben 4 példány maradványai voltak (1c., 2a. táblázat). A közönséges vízicikány (Neomys fodiens) maradványai ritkábban fordulnak elő a köpetekben, mint a Miller-vízicickányé, de a most feldolgozott anyagból három olyan területröl (Péterhida, XL89; Bolhó, XM70; Ötvöskónyi, XM82) is kimutattuk (1a., 1c., 1e., 2a, 2b. táblázat), amelyekről korábban nem került elő (PURGER 1998, 2002). A közönséges vakond (Talpa europaea) az ország egész területén megtalálható, gyakori faj (BIHARI 2007a), de földalatti életmódja miatt ritka zsákmánya a gyöngybaglyoknak. Többnyire nagyszámú köpetet kell begyűjteni és megtisztítani ahhoz, hogy maradványai előkerüljenek. A közönséges vakond jelenlétét most három (Csokonyavisonta és Rinyaújlak, XM80; Bőszénfa, YM12; Kaposszerdahely, YM13) olyan UTM négyzet területéről is kimutattuk (1d., 1h., 2b., 2c. táblázat), amelyekről a korábbi köpetvizsgálatok során nem tudtuk bizonyítani előfordulását (PURGER 1998, 2002, 2005). 
A feldolgozott köpetanyagban 4 denevérfaj 5 példányának maradványait is megtaláltuk. A közönséges késeidenevér (Eptesicus serotinus) maradványai már korábban is előkerültek az XM81-es UTM négyzet területérről, csak az 1996-ban gyüjtött minta a lábodi református templom padlásáról (PURGER 2002), míg a 2002ben gyűjtött és jelen dolgozatban közzétett minta a görgetegi református templom padlásáról származott (1e. táblázat). A szőröskarú koraidenevér (Nyctalus leisleri) maradványai Görgetegen (XM81), a rőt koraidenevéré (Nyctalus noctula) Lábadon (XM81) a közönséges denevéré (Myotis myotis) pedig Bolhón (XM70) és Görgetegen (XM81) gyűjtött köpetekböl kerültek elő (1c., 1d., 1e., 2a., 2b. táblázat). $E$ három faj jelenlétét a vizsgált területen a korábban végzett köpetvizsgálatok során nem tudtuk bizonyítani (PURGER 1998, 2002).

A köpetanyagban $57,6 \%$-os részesedéssel a rágcsálók (Rodentia) domináltak. A gyöngybaglyok ritkán zsákmányolnak peléket, de a mogyorós pele (Muscardinus avellanarius) jelenlétét három (Péterhida, XL89; Gyékényes, XM52; Csurgó, XM62) olyan UTM négyzet területéröl is sikerült kimutatni (1a., 1c., $2 a$. táblázat), melyekből a korábbi vizsgálataink során nem kerültek elő (PURGER 1998).

A gyöngybaglyok elsősorban nyilt területeken vadásznak (TAYLOR 1994), így a rágcsálók közül legnagyobb számban pocokféléket, elsősorban mezei pockot (Microtus arvalis) fogyasztanak. Ennek köszönhetően a kistermetű pocokfajok többségének elterjedéséröl rengeteg adattal rendelkezünk (BıHARI et al. 2007). A nagy testű kószapocok (Arvicola amphibia) már ritkábban kerül a zsákmány közé, de a gyöngybaglyok esetenként mégis elejtenek egy-egy, többnyire fiatal példányt. A nagy mintaszámnak köszönhetően, most öt (Péterhida, XL89; Bolhó, XM70; Bolhás és Somogyszob, XM72; Békepuszta és Szulok, XM90; Rinyakovácsi, YM02) olyan UTM négyzet területéről sikerült kimutatnunk a kósza pocok jelenlétét (1a., 1c., 1e., 1f., 1g., 2a-c. táblázat), amelyekből a korábban feldolgozott köpetminták segítségével nem tudtuk bizonyítani előfordulását (PURGER 1997, 1998, 2002). A vöröshátú erdeipocok (Myodes glareolus) esetében a gyékényesi adat (1c., 2a. táblázat) is újnak számít, mivel az XM52-es UTM négyzet területéről korábban nem kerültek elő bizonyító példányai (PURGER 1998).

A sárganyakú erdeiegér (Apodemus flavicollis), a közönséges erdeiegér ( $A$. sylvaticus) és a pirókegér ( $A$. agrarius) gyakori zsákmányai a gyöngybaglyoknak. A kislábú erdeiegér (Apodemus uralensis) előfordulásáról Somogy megye területén azonban másfél évtizeddel ezelőtt még nem volt tudomásunk (LANSZKI \& PURGER 2001). Az első koponyamaradvány Somogyjádról (YM05) került elő, a református templomban 1999ben gyűjtött köpetekből (PURGER 2008). Emellett további 12 példány előfordulási adatait ismerjük (XM85, XM96, YM15, YM18, YM25, YM27, BS75, BS88, BS89) (Purger 2008, 2013, 2014a, 2014b). A kisemlősök elevenfogó csapdákkal történő monitorozásának köszönhetően, a korábban csak köpetekből kimutatott kislábú erdeiegeret már kisemlös csapdával is sikerült megfogni (LANSZKI et al. 2015). A most feldolgozott mintából, mindössze egy koponya csonttani bélyegei alapján tudtuk biztosan kijelenteni, hogy a Homokszentgyörgyön (XM91) gyűjtött köpetekben (1f., 2b. táblázat) is volt egy kislábú erdeigér. Homokszentgyörgy az eddig ismert lelőhelyektől mintegy 40 km-rel délebbre található. Somogy megye a kislábú erdeiegér elterjedési területének délnyugati határán van (CSERKÉSz \& HORVÁTH 2007), így az sem zárható ki, hogy csak az utóbbi másfél-két évtizedben települt be a megye területére. Az is elképzelhető, hogy a kislábú erdeigér már azelőtt is ott volt, csak korábban nem folytak szisztematikus kisemlős felmérések, ezért nem volt tudomásunk előfordulásáról.

Jelen dolgozatban a güzüegér (Mus spicilegus) és a háziegér (Mus musculus) adatai külön szerepelnek így hozzájárulnak a két faj elterjedési mintázatának tisztázásához. A két faj elterjedési adatainak összevetése a korábbi adatokkal nehézségekbe ütközik, mivel a nyolcvanas évek végéig a güzüegeret a háziegér alfajának tekintették, így előfordulási adatai összemosódtak a háziegérével (BIHARI 2007b). A házi patkány (Rattus rattus) magyarországi előfordulásáról kevés információnk van, ezért minden újabb előfordulási adatot érdemes kiemelni. A mostani anyagból, a szuloki katolikus templom padlásán (XM90) 1997-ben gyűjtött mintából kerültek elő a maradványai (1f. táblázat). Ebből az UTM négyzetből a Szulokhoz közeli Békepusztán 1993-ban gyűjtött köpetmintából előkerült csontmaradványok már bizonyították jelenlétét (PURGER 1997). A vándorpatkány (Rattus norvegicus) a házi patkánynál jóval gyakoribb és elterjedtebb faj, és a gyöngybagoly köpetekből is rendszeresen előkerülnek maradványai. A vándorpatkány új előfordulását Drávagárdony (YL09), Gyékényes (XM52) és Bolhó (XM70) környékén (1b., 1c., 2a. táblázat) bizonyítottuk, ami azért jelentős, mivel a felsorolt UTM négyzetek területéről a korábbi mintákból nem sikerült kimutatnunk (PURGER 1998).

A menyét ( $M$. nivalis), mint ragadozó emlős, nagyon ritkán fordul elő a baglyok zsákmányállatai között. A Péterhidán (XL89) gyűjtött köpetekben azonban megtaláltuk egy példány maradványait (1a., 2a. táblázat), ami azért is fontos, mivel a területen a korábbi köpetgyűjtések során nem sikerült bizonyítani jelenlétét (PURGER 1998), és a menyét elterjedési térképén sem jelölték előfordulását ezen a lelöhelyen (HELTAI \& LANSZKI 2007).

A köpetekből kimutatott 27 kisemlős faj közül 15 védett (1a-i, 2a-c. táblázat). A közzétett adatok jelentős hányada csak megerősíti korábbi ismereteinket egyes fajok elterjedéséről, de 9 kisemlős faj esetében újabb előfordulási adatokkal pontosítottuk elterjedési mintázatuk ismeretét (2a-c. táblázat).

\section{Köszönetnyilvánítás}

Köszönöm Fenyősi Lászlónak, Horváth Zoltánnak, Mezei Ervinnek, Pintér Andrásnak, Sípter Csanádnak és a Gyöngybagolyvédelmi Alapítvány munkatársainak a köpetek begyűjtésénél, Dr. Csorba Gábornak és Görföl Tamásnak a denevérek meghatározásánál, Légvári Katalinnak és Purger Eleonorának pedig a köpetek tisztításában nyújtott segítséget. 


\section{Irodalom}

Ács, A. 1985: A bagolyköpetvizsgálatok alapjai. - A Magyar Madártani Egyesület Zalai Helyi Csoportjának kiadványa, Zalaegerszeg, 58 pp.

BAlogh, L., Hajdú. M., Hosszú, F., KIRÁly, L., MARKó, I. L., ÖRdöG, F., Pesti, J., Szabó, J. és Szabó, L. 1974: Somogy megye földrajzi nevei. Akadémiai Kiadó, Budapest,1174 pp.

BIHARI, Z. 2007a: Közönséges vakond. - Pp. 67-68. In: BIHARI, Z., CsorbA, G. \& HeltAI, M. (ed.): Magyarország emlőseinek atlasza. - Kossuth Kiadó, Budapest. 360 pp.

BIHARI, Z. 2007b: Güzüegér. - Pp. 195-196. In: BIHARI, Z., CsoRBA, G. \& HeLtAI, M. (ed.): Magyarország emlöseinek atlasza. - Kossuth Kiadó, Budapest. 360 pp.

BIHARI, Z., CsORBA, G. és HeLTAI, M. (ed.) 2007: Magyarország emlőseinek atlasza. - Kossuth Kiadó, Budapest. 360 pp.

BunN, D. S., Warburton, A. B. \& Wilson R. D. S. 1982: The Barn OwI. - Calton, T. \& A. D. Poyser, 288 pp.

CSERKÉSz, T. \& HORVÁTH, GY. 2007. Kislábú erdeiegér. - PP. 189-190. In BIHARI, Z., CsorbA, G. \& HeltAI, M. (ed.): Magyarország emlöseinek atlasza. Kossuth Kiadó, Budapest. 360 pp.

DÉVAl, GY., MısKOLCZı, M. \& TóTH, S. 1997: Egységesítési javaslat a névhasználatra és az UTM rendszerū kódolásra a biotikai adatok lelöhelyeinél. - Acta Biologica Debrecina Supplementum Oecologica Hungarica 8: 13-42.

GonZÁLEZ-FISCHer, C. M., Codesido, M., TETA, P. \& BILENCA, D. 2011 Seasonal and geographic variation in the food habits of the Barn Owl (Tyto alba) in temperate agroecosystems of Argentina. Ornitologia Neotropical 22: 295-305

HeLtal, M. és LANSZKI, J. 2007: Eurázsiai menyét. Pp. 232-233. In: BIHARI, Z., CsoRBA, G. \& HeLTAI, M. (ed.): Magyarország emlöseinek atlasza. Kossuth Kiadó, Budapest. 360 pp.

KRYŠTUFEK, B. 1985: Mali sesalci. - Naša rodna zemlja 4. Prirodoslovno društvo Slovenije, Ljubljana, $30 \mathrm{pp}$.

KRYŠTUFEK, B. 1991: Sesalci Slovenije. - Prirodoslovni muzej Slovenije, Ljubljana, $294 \mathrm{pp}$

KRYŠTUFEK, B. \& JANŽEKovič, F. (ed.) 1999: Ključ za določanje vretenčarjev Slovenije. - DZS, Lubljana, $544 \mathrm{pp}$.

LANSZKI, J. \& PURGER, J. J. 2001: Somogy megye emlős faunája (Mammalia). - Natura Somogyiensis 1: 481-494.

LANSZKI, J., RozNER, GY. \& SzÉLES, L. G. 2015: A Pogány-völgyi rétek Natura 2000 terület kisemlős közösségeinek vizsgálata, különös tekintettel az északi pocok (Microtus oeconomus) előfordulására. - Natura Somogyiensis 27: 107-114.

MACHOLÁN, M. 1996: Key to European house mice (Mus). - Folia Zoologica 45(3): 209-217

MÄRZ, R. 2011: Gewöll- und Rupfungskunde. - AULA Verlag, Berlin, pp. 406.

MıkkolA, H. 1983: Owls of Europe. T. \& A. D. Poyser, Calton, pp. 397.

MIKUSKA, J., TVRTKOVIĆ, N. \& DžUKıć, G. 1979: Sakupljanje i analiza gvalica ptica kao jedna od važnih metoda upoznavanja faune naših sisara. - Arhiv bioloških nauka 29(3-4): 157-160.

Miskolczı, M., DÉval, GY., KeRTÉsz, Gy. \& BAJZA, Á. 1997: A magyarországi helységek kódjegyzéke az UTM rendszerü $10 \times 10 \mathrm{~km}$ beosztású hálótérkép szerint. Acta Biologica Debrecina Supplementum Oecologica Hungarica 8: 43-194.

Niethammer, J. \& KRAPP, F. (ed.) 1978: Handbuch der Säugetiere Europas. - Band 1. Nagetiere I. Akademische Verlagsgesellschaft, Wiesbaden, $476 \mathrm{pp}$

Niethammer, J. \& KRAPP, F. (ed.) 1982: Handbuch der Säugetiere Europas. - Band 2/l. Nagetiere II. Akademische Verlagsgesellschaft, Wiesbaden. 649 pp.

Niethammer, J. \& KRAPP, F. (ed.) 1990: Handbuch der Säugetiere Europas. - Band 3/I. Insektenfresser, Herrentiere. AULA-Verlag, Wiesbaden. $523 \mathrm{pp}$.
PURgeR, J. J. 1996: A Boronka-melléki Tájvédelmi Körzet keleti határvidékének (Somogy megye) kisemlős faunája, gyöngybagoly, Tyto alba (Scopoli, 1769) köpetek vizsgálata alapján. - Somogyi Múzeumok Közleményei 12: 299-302.

PuRger, J. J. 1997: A csokonyavisontai halastavak (Somogy megye) környékének kisemlös faunája, gyöngybagoly köpetek vizsgálata alapján. - Természetvédelmi Közlemények 5-6: 105-109.

PuRger, J. J. 1998: A Dráva mente Somogy megyei szakaszának kisemlös (Mammalia) faunája, gyöngybagoly, Tyto alba (Scopoli, 1769) köpetek vizsgálata alapján. - Dunántúli Dolgozatok (A) Természettudományi Sorozat 9: 489-500.

PuRger, J. J. 2002: A Somogyszob, Hajmás és Kálmáncsa közötti térség kisemlős faunája, gyöngybagoly Tyto alba (Scopoli, 1769) köpetek vizsgálata alapján. - Natura Somogyiensis 3: 99-110.

PuRger, J. J. 2004: Varászló, Somogysárd, Iharos és Csököly környékének, valamint az általuk határolt térség (Somogy megye) kisemlős faunája, gyöngybagoly Tyto alba (Scopoli, 1769) köpetek vizsgálata alapján. - Somogyi Múzeumok Közleményei 16: 409-419.

PURGER, J. J. 2005: Kaposvár és környékének (Somogy megye) kisemlős faunája, gyöngybagoly Tyto alba (Scopoli, 1769) köpetek vizsgálata alapján. - Folia Historico-naturalia Musei Matraensis 29: 203-215.

PuRger, J. J. 2008: Öreglak, Kürtöspuszta, Törökkoppány és Kazsok környékének (Somogy megye), valamint az általuk határolt térség kisemlősfaunájának vizsgálata, gyöngybagoly- (Tyto alba (Scopoli, 1769)) köpetek alapján. - Állattani Közlemények 93: 65-76.

PuRgeR, J. J. 2013: Kisemlősök faunisztikai felmérése Somogy megye északkeleti részén, gyöngybagoly Tyto alba (Scopoli, 1769) köpetek vizsgálata alapján. - A Kaposvári Rippl-Rónai Múzeum Közleményei 1: 81-90.

PuRger, J. J. 2014a: Kisemlösök faunisztikai felmérése Külső-Somogy északnyugati részén, gyöngybagoly Tyto alba (Scopoli, 1769) köpetek vizsgálata alapján. - A Kaposvári Rippl-Rónai Múzeum Közleményei 3: 105-112.

PuRger, J. J. 2014b: Survey of the small mammal fauna in north-western Somogy county (Hungary), based on Barn Owl Tyto alba (Scopoli, 1769) pellet analysis. - Natura Somogyiensis 24: 293-304

SCHMIDT, E. 1967: Bagolyköpetvizsgálatok. - Magyar Madártani Intézet. Budapest, $137 \mathrm{pp}$.

TAYLOR, I. R. 1994: Barn Owls: Predator- Prey Relationships and Conservation. Cambridge University Press, Cambridge, 304 pp.

TVRTKOVIĆ, N. 1979: Razlikovanje i određivanje morfološki sličnih vrsta podroda Sylvaemus Ognev \& Vorobiev 1923 (Rodentia, Mammalia). - Rad JAZU 383: 155-186.

TVRTKOVIĆ, N., ĐULIĆ, B. \& MRAKOVČIĆ, M. 1980: Distribution, species characters, and variability of the Southern water-shrew, Neomys anomalus Cabrera, 1907 (Insectivora, Mammalia) in Croatia. Biosistematika 6(2): 187-201.

UJHELYI, P. 1989: A magyarországi vadonélő emlösállatok határozója (Küllemi és csonttani bélyegek alapján). - A Magyar Madártani és Természetvédelmi Egyesület (MME) Könyvtára 1. Budapest, 185 pp.

YaLden, D. W. 1977: The Identification of remains in Owl Pellets. - An Occasional Publication of the Mammal Society No. 2. Reading, 8 pp.

YAlden, D. W. \& MorRis, P. A. 1990: The Analysis of Owl Pellets. - An Occasional Publication of the Mammal Society No. 13. London, 24 pp.

ZÖRÉNYI, M. 1990: A bagolyköpetekböl várható hazai emlösfajok határozókulcsa. - Babits füzetek 1. Babits Mihály Művelődési Központ, Szekszárd. 34 pp. 
1a. táblázat. A gyöngybagoly köpetmintákból (1-12) előkerült zsákmányállatok száma.

Table 1a. Number of prey specimens in pellets of Barn Owl in samples 1-12.

\begin{tabular}{|c|c|c|c|c|c|c|c|c|c|c|c|c|}
\hline Minták - Samples & 1. & 2. & 3. & 4. & 5. & 6. & 7. & 8. & 9. & 10. & 11. & 12. \\
\hline 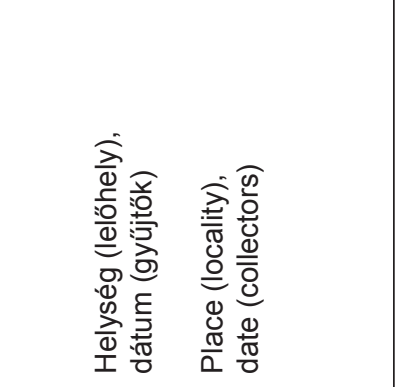 & 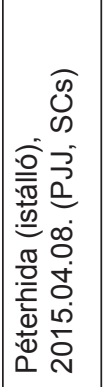 & 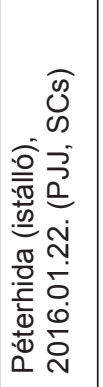 & 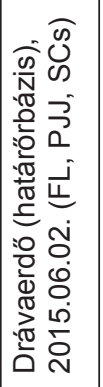 & 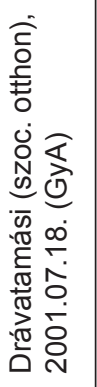 & 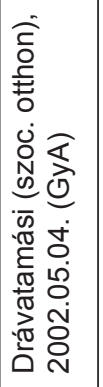 & 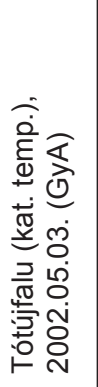 & 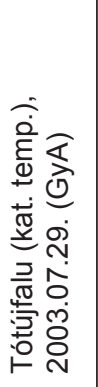 & 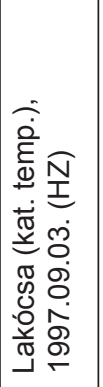 & 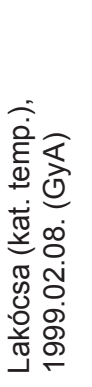 & 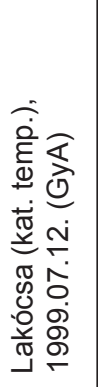 & 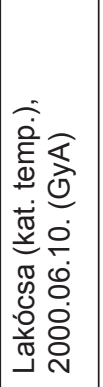 & 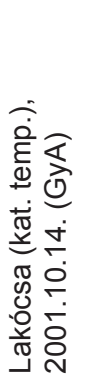 \\
\hline UTM (10x10 km) & XL89 & XL89 & XL89 & XL99 & XL99 & YL08 & YL08 & YL08 & YL08 & YL08 & YL08 & YL08 \\
\hline Crocidura leucodon & 58 & 85 & 23 & 2 & & 1 & 16 & 14 & 3 & 7 & 3 & \\
\hline Crocidura suaveolens & 42 & 63 & 9 & 1 & 9 & 3 & 7 & 34 & 35 & 30 & 81 & 8 \\
\hline Sorex araneus & 53 & 41 & 4 & 3 & 1 & 1 & 5 & 12 & 1 & 19 & 31 & 1 \\
\hline Sorex minutus & 35 & 20 & 2 & & & 1 & & 5 & & 4 & 7 & \\
\hline Neomys anomalus & 7 & 47 & 7 & & & & & 11 & 2 & 21 & 51 & 1 \\
\hline Neomys fodiens & & 2 & & & & & & 3 & & & 2 & \\
\hline Muscardinus avellanarius & 1 & & & & & & & & & 1 & & \\
\hline Microtus agrestis & 3 & 14 & & & & 2 & 1 & 4 & 7 & 11 & 12 & 2 \\
\hline Microtus arvalis & 48 & 61 & 24 & 46 & 7 & 63 & 29 & 37 & 29 & 40 & 35 & 18 \\
\hline Microtus subterraneus & 7 & 6 & & & & & 1 & 1 & 1 & 1 & & 1 \\
\hline Arvicola amphibius & & 1 & & & & & & & & 4 & 2 & \\
\hline Myodes glareolus & 9 & 13 & 5 & 2 & & & & 2 & & 2 & 3 & 2 \\
\hline Apodemus agrarius & 28 & 34 & 28 & 11 & 3 & 15 & & 16 & 9 & 25 & 15 & 4 \\
\hline Apodemus flavicollis & 7 & 10 & 3 & 3 & & & 2 & 3 & 1 & 8 & 4 & \\
\hline Apodemus sylvaticus & 2 & 8 & 3 & 6 & 1 & 1 & & 5 & & 1 & 1 & \\
\hline Apodemus sp. & 1 & 11 & 5 & & & & 3 & 2 & 1 & 4 & 1 & \\
\hline Micromys minutus & 5 & 10 & & & & & & 8 & & 14 & 13 & \\
\hline Mus musculus & 3 & 3 & 2 & 6 & 1 & 3 & 1 & 1 & & 3 & 8 & \\
\hline Mus spicilegus & 2 & & 2 & 3 & & & & 1 & & 2 & 1 & \\
\hline Mus sp. & & & & & & & & & 1 & 1 & & \\
\hline Rattus norvegicus & & & & 7 & 2 & 2 & & & & & & \\
\hline Rattus sp. & & & & 2 & & & & & & & 1 & \\
\hline Mustela nivalis & 1 & & & & & & & & & & & \\
\hline Aves (indet.) & 2 & 3 & & 3 & & 1 & & & & 2 & 1 & \\
\hline Amphibia (Pelobates fuscus) & 2 & & & & & & & & 1 & & & \\
\hline Amphibia (Rana sp.) & & & & & & & & & & 1 & & \\
\hline Coleoptera (indet.) & & & & & & & & & & 8 & & \\
\hline Zsákmány / Prey & 316 & 432 & 117 & 95 & 24 & 93 & 65 & 159 & 91 & 209 & 272 & 37 \\
\hline Köpet / Pellet & 100 & 185 & 61 & 48 & 6 & 34 & 21 & 54 & 26 & 67 & 74 & 15 \\
\hline
\end{tabular}


1b. táblázat. A gyöngybagoly köpetmintákból (13-24) előkerült zsákmányállatok száma. Table 1b. Number of prey specimens in pellets of Barn Owl in samples 13-24.

\begin{tabular}{|c|c|c|c|c|c|c|c|c|c|c|c|c|}
\hline Minták - Samples & 13. & 14. & 15. & 16. & 17. & 18. & 19. & 20. & 21. & 22. & 23. & 24. \\
\hline 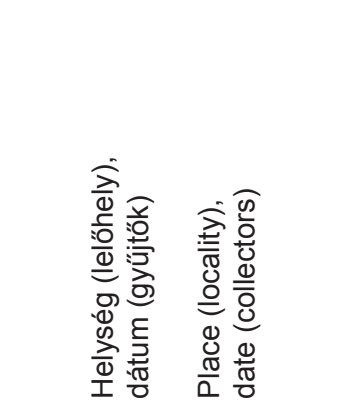 & 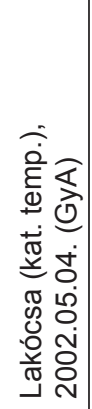 & 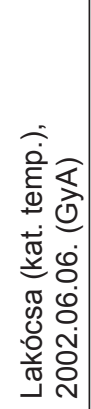 & 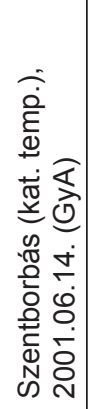 & 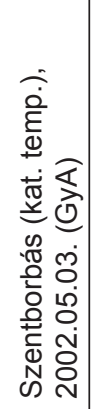 & 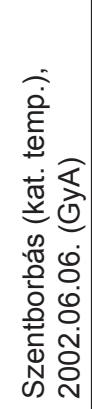 & 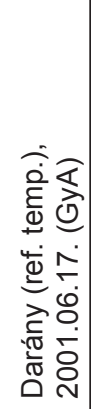 & 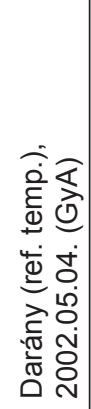 & 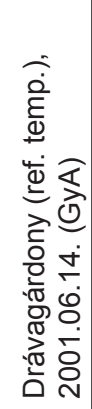 & 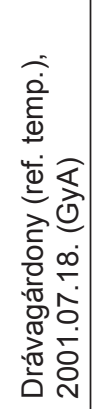 & 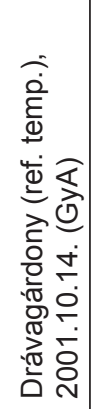 & 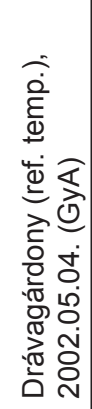 & 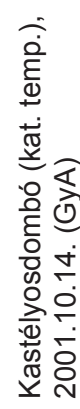 \\
\hline UTM (10x10 km) & YL08 & YL08 & YL08 & YL08 & YL08 & YL09 & YL09 & YL09 & YL09 & YL09 & YL09 & YL09 \\
\hline Crocidura leucodon & 2 & 3 & 2 & 1 & 3 & 5 & 1 & 3 & 1 & & 2 & \\
\hline Crocidura suaveolens & 15 & 9 & 23 & 5 & 6 & 13 & 5 & 11 & 13 & 3 & 4 & \\
\hline Sorex araneus & 11 & 4 & 1 & & 1 & 6 & 8 & 4 & 1 & & 3 & 1 \\
\hline Sorex minutus & 2 & & & 1 & & 1 & 1 & 2 & 1 & & 1 & \\
\hline Neomys anomalus & & & & 1 & & & 1 & 1 & 1 & & & \\
\hline Muscardinus avellanarius & 2 & & & & & & & & & & & \\
\hline Microtus agrestis & 44 & 21 & 1 & 1 & 2 & 2 & 4 & 7 & 3 & 5 & & \\
\hline Microtus arvalis & 74 & 69 & 50 & 31 & 56 & 104 & 80 & 59 & 62 & 36 & 31 & 21 \\
\hline Microtus subterraneus & 4 & 3 & & & & 2 & & & 1 & & 1 & \\
\hline Arvicola amphibius & 2 & & & & & 4 & & 1 & 1 & 1 & 1 & \\
\hline Myodes glareolus & & 2 & 1 & & & & & 4 & 2 & & 1 & \\
\hline Apodemus agrarius & 3 & 2 & 1 & 2 & 3 & 11 & 9 & 9 & 9 & 2 & 4 & \\
\hline Apodemus flavicollis & 5 & 8 & 8 & 1 & 4 & 4 & 2 & 8 & 6 & 3 & 3 & 1 \\
\hline Apodemus sylvaticus & 1 & 1 & 4 & 4 & 2 & 9 & 1 & & 3 & 1 & 1 & 1 \\
\hline Apodemus sp. & & 1 & 5 & 7 & 1 & 9 & 3 & 7 & 3 & 3 & & 1 \\
\hline Micromys minutus & 1 & & 1 & & & 2 & & & 1 & & & \\
\hline Mus musculus & 5 & 4 & 4 & & 2 & & 1 & 2 & 4 & & 1 & \\
\hline Mus spicilegus & 2 & & 1 & 1 & 3 & 1 & 1 & 1 & & & 1 & \\
\hline Rattus norvegicus & & & & & & & & 6 & 3 & 5 & 2 & \\
\hline Aves (indet.) & 2 & & & & & 2 & 1 & 3 & & & 1 & \\
\hline Amphibia ( $P$. fuscus) & & & & & & 1 & & & & & & \\
\hline Zsákmány / Prey & 175 & 127 & 102 & 55 & 83 & 176 & 118 & 128 & 115 & 59 & 57 & 25 \\
\hline Köpet / Pellet & 65 & 56 & 35 & 25 & 28 & 92 & 54 & 60 & 47 & 28 & 23 & 13 \\
\hline
\end{tabular}


1c. táblázat. A gyöngybagoly köpetmintákból (25-36) előkerült zsákmányállatok száma. Table 1c. Number of prey specimens in pellets of Barn Owl in samples 25-36.

\begin{tabular}{|c|c|c|c|c|c|c|c|c|c|c|c|c|}
\hline Minták - Samples & 25. & 26. & 27. & 28. & 29. & 30. & 31. & 32. & 33. & 34. & 35. & 36. \\
\hline 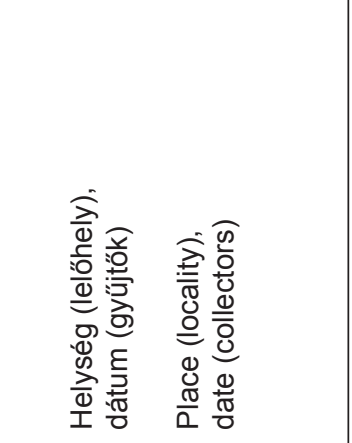 & 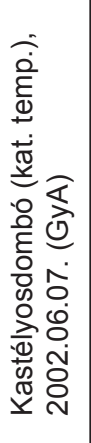 & 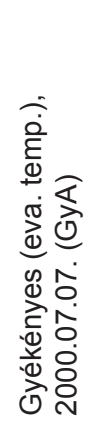 & 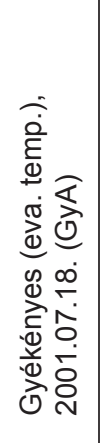 & 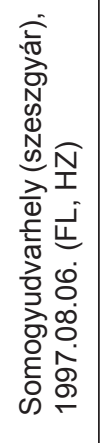 & 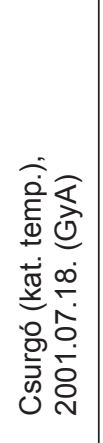 & 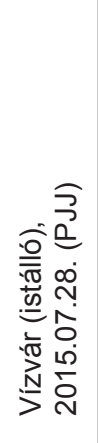 & 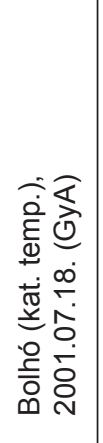 & 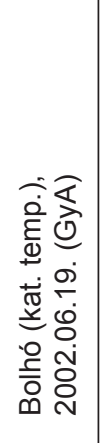 & 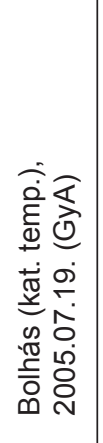 & 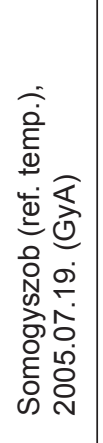 & 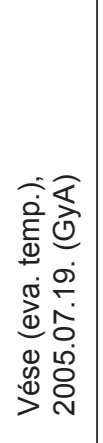 & 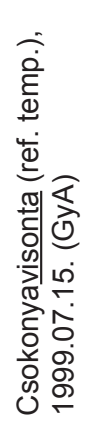 \\
\hline UTM (10x10 km) & YL09 & XM52 & XM52 & XM61 & XM62 & XM70 & XM70 & XM70 & XM72 & XM72 & XM74 & XM80 \\
\hline Crocidura leucodon & 5 & 6 & 4 & 1 & 2 & 2 & & 1 & 20 & 20 & 20 & 2 \\
\hline Crocidura suaveolens & 3 & 11 & 8 & 17 & 16 & 3 & 4 & 2 & 6 & 8 & 14 & 5 \\
\hline Sorex araneus & 4 & 98 & 22 & 43 & 23 & 2 & 13 & 14 & 16 & 27 & 28 & 27 \\
\hline Sorex minutus & 4 & 26 & 2 & 17 & 3 & 2 & 3 & 3 & 7 & 11 & 6 & \\
\hline Neomys anomalus & & 15 & & 22 & 4 & & 3 & 1 & & 2 & & 10 \\
\hline Neomys fodiens & & 1 & 1 & 5 & 2 & & 1 & & & & & 1 \\
\hline Myotis myotis & & & & & & & & 1 & & & & \\
\hline Muscardinus avellanarius & 1 & 1 & & & 1 & & 1 & & & & & \\
\hline Microtus agrestis & 5 & 5 & 1 & 4 & 6 & 2 & 2 & 5 & 1 & 7 & 1 & 21 \\
\hline Microtus arvalis & 44 & 47 & 54 & 38 & 68 & 5 & 13 & 26 & 16 & 28 & 26 & 23 \\
\hline Microtus subterraneus & 2 & 2 & & 2 & 9 & & & 2 & 2 & 2 & 6 & 1 \\
\hline Arvicola amphibius & 1 & & & & 2 & & & 2 & 2 & 3 & & 1 \\
\hline Myodes glareolus & & 1 & & & 5 & & 3 & 4 & 5 & 7 & 1 & \\
\hline Apodemus agrarius & 11 & 4 & 2 & 4 & 13 & & 3 & 9 & 8 & 11 & 3 & 9 \\
\hline Apodemus flavicollis & 1 & 1 & & & 10 & & 5 & 4 & 3 & 4 & 4 & \\
\hline Apodemus sylvaticus & & 1 & 4 & 1 & 21 & & 3 & 2 & 5 & 9 & 1 & 2 \\
\hline Apodemus sp. & 5 & & 1 & & 14 & & 1 & 2 & 1 & 1 & 5 & 1 \\
\hline Micromys minutus & & 1 & & 7 & 1 & & 2 & & 1 & 3 & 1 & 2 \\
\hline Mus musculus & & 5 & 1 & 1 & 8 & 1 & & 1 & 13 & 1 & 9 & 2 \\
\hline Mus spicilegus & & & & & 2 & & 1 & & & 1 & & \\
\hline Rattus norvegicus & & 1 & & & & & & 2 & 18 & 9 & & \\
\hline Rattus sp. & & & & & & & & 1 & 2 & & & \\
\hline Aves (indet.) & 2 & & & & & 1 & 1 & & 8 & 7 & 1 & 1 \\
\hline Amphibia (P. fuscus) & & & & & & 3 & & & & & & \\
\hline Zsákmány / Prey & 88 & 226 & 100 & 162 & 210 & 21 & 59 & 82 & 134 & 161 & 126 & 108 \\
\hline Köpet / Pellet & 42 & 60 & 35 & 36 & 92 & 6 & 29 & 31 & 57 & 68 & 43 & 39 \\
\hline
\end{tabular}


1d. táblázat. A gyöngybagoly köpetmintákból (37-48) előkerült zsákmányállatok száma. Table 1d. Number of prey specimens in pellets of Barn Owl in samples 37-48.

\begin{tabular}{|c|c|c|c|c|c|c|c|c|c|c|c|c|}
\hline Minták / Samples & 37. & 38. & 39. & 40. & 41. & 42. & 43. & 44. & 45. & 46. & 47. & 48. \\
\hline 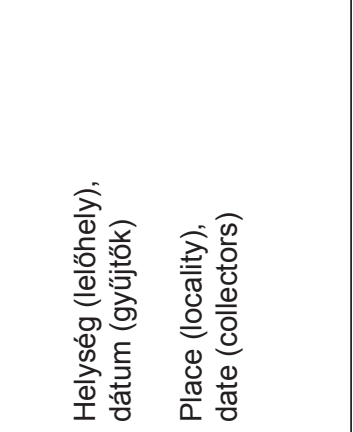 & 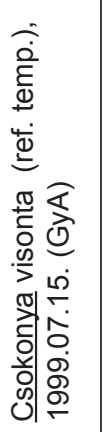 & 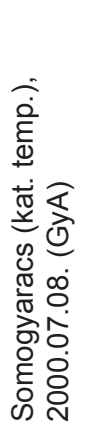 & 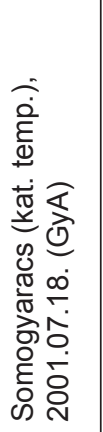 & 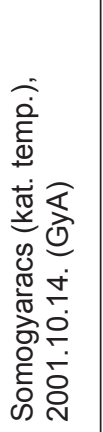 & 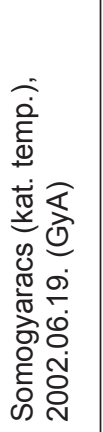 & 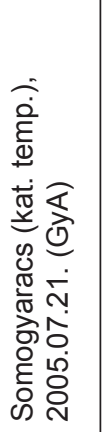 & 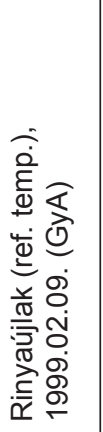 & 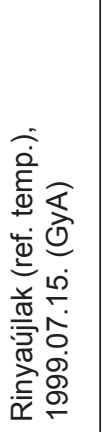 & 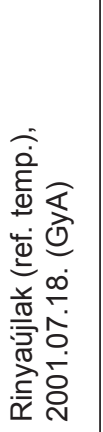 & 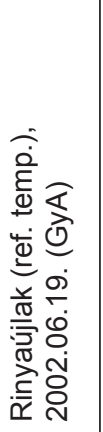 & 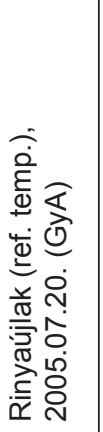 & 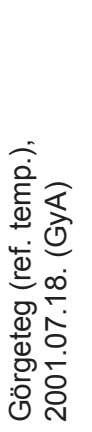 \\
\hline UTM (10x10 km) & XM80 & XM80 & XM80 & XM80 & XM80 & XM80 & XM80 & XM80 & XM80 & XM80 & XM80 & XM81 \\
\hline Crocidura leucodon & 2 & 6 & 15 & 7 & 8 & 67 & & 1 & 20 & 12 & 39 & 2 \\
\hline Crocidura suaveolens & 17 & 9 & 42 & 6 & 6 & 83 & 4 & 8 & 26 & 34 & 44 & 8 \\
\hline Sorex araneus & 17 & 27 & 83 & 4 & 28 & 27 & 4 & 3 & 81 & 24 & 34 & 11 \\
\hline Sorex minutus & 10 & 8 & 34 & & 7 & 12 & 1 & 3 & 10 & 8 & 14 & 1 \\
\hline Neomys anomalus & 2 & 1 & 11 & 1 & 1 & 5 & 1 & 4 & 27 & 7 & 5 & 3 \\
\hline Neomys fodiens & & 1 & 1 & & & 2 & & & 4 & 2 & & 1 \\
\hline Talpa europaea & 1 & & & & & & & & & 1 & & \\
\hline Nyctalus leisleri & & & & & & & & & & & & 1 \\
\hline Muscardinus avellanarius & & & & 1 & 1 & 1 & 1 & & & 1 & & \\
\hline Microtus agrestis & 10 & 5 & 4 & 1 & 2 & 5 & 5 & 5 & 16 & 17 & 8 & 7 \\
\hline Microtus arvalis & 34 & 10 & 27 & 18 & 28 & 66 & 5 & 10 & 30 & 74 & 69 & 12 \\
\hline Microtus subterraneus & & 3 & 27 & 7 & 6 & 18 & & & 5 & 16 & 12 & 5 \\
\hline Arvicola amphibius & 1 & 1 & 3 & & & & & & 3 & 2 & & \\
\hline Myodes glareolus & 5 & 1 & 14 & 4 & 4 & 14 & 2 & & 12 & 6 & 5 & \\
\hline Apodemus agrarius & 18 & 4 & 32 & 4 & 15 & 31 & 4 & 9 & 20 & 21 & 24 & 2 \\
\hline Apodemus flavicollis & & 2 & 15 & 3 & 2 & 9 & & & 14 & 6 & 15 & 3 \\
\hline Apodemus sylvaticus & 1 & 2 & 13 & 3 & 4 & 4 & & & 1 & 7 & 9 & 4 \\
\hline Apodemus sp. & 2 & 3 & 10 & 1 & 2 & 8 & & 2 & 8 & 7 & 5 & 3 \\
\hline Micromys minutus & 2 & 6 & 2 & & & 3 & 2 & 3 & 1 & 1 & & \\
\hline Mus musculus & 1 & 1 & & & 1 & 17 & 1 & & 2 & 4 & 13 & 1 \\
\hline Mus spicilegus & 1 & 1 & 2 & 1 & 2 & 1 & 1 & & & 5 & 1 & 1 \\
\hline Rattus norvegicus & 3 & 1 & 14 & & 5 & 4 & 1 & & & & 1 & \\
\hline Rattus sp. & & 2 & 1 & 2 & 1 & 1 & & 1 & & & & \\
\hline Aves (indet.) & & 4 & 1 & 2 & 1 & & & & 1 & 1 & 1 & \\
\hline Amphibia ( $P$. fuscus) & & & 3 & & & & & & 1 & & & 1 \\
\hline Zsákmány / Prey & 127 & 98 & 354 & 65 & 124 & 378 & 32 & 49 & 282 & 256 & 299 & 66 \\
\hline Köpet / Pellet & 39 & 36 & 110 & 27 & 43 & 141 & 11 & 18 & 77 & 94 & 112 & 23 \\
\hline
\end{tabular}


1e. táblázat. A gyöngybagoly köpetmintákból (49-60) elökerült zsákmányállatok száma. Table 1e. Number of prey specimens in pellets of Barn Owl in samples 49-60.

\begin{tabular}{|c|c|c|c|c|c|c|c|c|c|c|c|c|}
\hline Minták / Samples & 49. & 50. & 51. & 52. & 53. & 54. & 55. & 56. & 57. & 58. & 59. & 60. \\
\hline 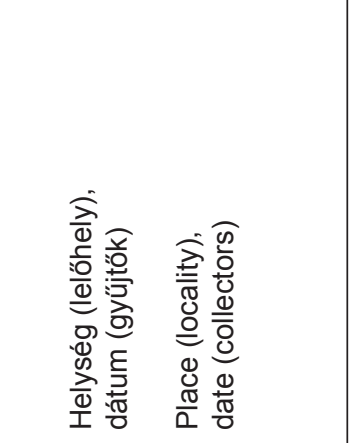 & 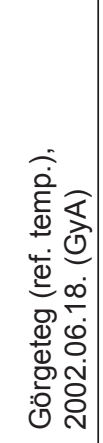 & 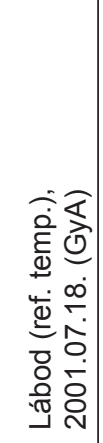 & 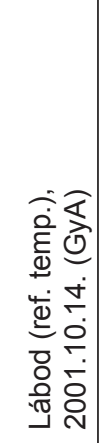 & 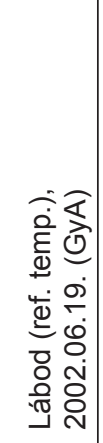 & 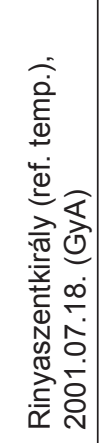 & 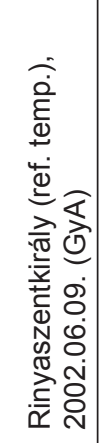 & 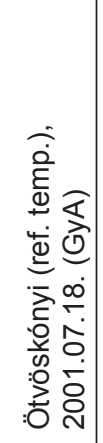 & 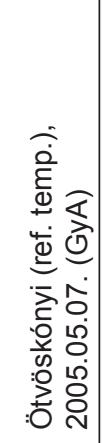 & 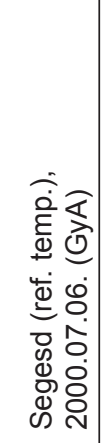 & 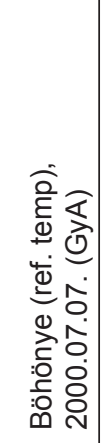 & 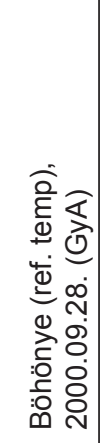 & 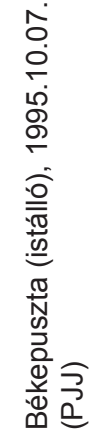 \\
\hline UTM (10x10 km) & XM81 & XM81 & XM81 & XM81 & XM81 & XM81 & XM82 & XM82 & XM83 & XM84 & XM84 & XM90 \\
\hline Crocidura leucodon & 6 & 14 & 7 & 4 & 3 & 8 & & 18 & 3 & & 1 & 95 \\
\hline Crocidura suaveolens & 8 & 19 & 3 & 5 & 9 & 6 & 10 & 23 & 20 & 9 & 5 & 65 \\
\hline Sorex araneus & 5 & 83 & 16 & 13 & 6 & 7 & 13 & 17 & 87 & 17 & 14 & 7 \\
\hline Sorex minutus & 1 & 14 & 3 & 2 & 1 & 2 & & 7 & 7 & 3 & 1 & \\
\hline Neomys anomalus & & 35 & 5 & & 3 & & & 2 & 14 & 2 & 2 & 6 \\
\hline Neomys fodiens & & 2 & 1 & 2 & & & 1 & 1 & 1 & & & \\
\hline Eptesicus serotinus & 1 & & & & & & & & & & & \\
\hline Nyctalus noctula & & 1 & & & & & & & & & & \\
\hline Myotis myotis & 1 & & & & & & & & & & & \\
\hline Muscardinus avellanarius & 1 & & 1 & & & & & 1 & & & & \\
\hline Microtus agrestis & 3 & 10 & 9 & 3 & & 3 & 1 & 5 & 3 & 3 & & 1 \\
\hline Microtus arvalis & 32 & 28 & 17 & 27 & 25 & 24 & 42 & 93 & 48 & 21 & 11 & 81 \\
\hline Microtus subterraneus & 3 & 8 & 3 & & 7 & 2 & 9 & 9 & 2 & 3 & & 2 \\
\hline Arvicola amphibius & 1 & 3 & & 1 & 3 & & & & 1 & & & 5 \\
\hline Myodes glareolus & & 3 & 4 & 2 & 1 & 3 & 1 & 12 & & & & \\
\hline Apodemus agrarius & 5 & 8 & 10 & 5 & 4 & 5 & 2 & 12 & 3 & 3 & 2 & 35 \\
\hline Apodemus flavicollis & 4 & 10 & 8 & 3 & 6 & & 2 & 8 & & 1 & & 7 \\
\hline Apodemus sylvaticus & 9 & 7 & 3 & 3 & 6 & & 7 & 16 & 3 & 5 & & 9 \\
\hline Apodemus sp. & 2 & 7 & 6 & 4 & 7 & 1 & 1 & 5 & & 1 & 1 & 10 \\
\hline Micromys minutus & & 2 & & & & & 1 & 2 & & 2 & & 7 \\
\hline Mus musculus & 4 & 2 & 1 & & & & & 5 & 2 & 1 & 2 & 1 \\
\hline Mus spicilegus & 7 & 4 & & 2 & & 1 & 4 & 1 & 1 & 2 & 1 & 10 \\
\hline Mus sp. & & & & & & & & & & & & 1 \\
\hline Aves (indet.) & 1 & & & & & & & 1 & & & & \\
\hline Amphibia ( $P$. fuscus) & & & & & & & & & 1 & & & \\
\hline Zsákmány / Prey & 94 & 260 & 97 & 76 & 81 & 62 & 94 & 238 & 196 & 73 & 40 & 342 \\
\hline Köpet / Pellet & 38 & 88 & 39 & 28 & 33 & 24 & 37 & 93 & 46 & 29 & 13 & 98 \\
\hline
\end{tabular}


1f. táblázat. A gyöngybagoly köpetmintákból (61-72) előkerült zsákmányállatok száma. Table 1f. Number of prey specimens in pellets of Barn Owl in samples 61-72.

\begin{tabular}{|c|c|c|c|c|c|c|c|c|c|c|c|c|}
\hline Minták / Samples & 61. & 62. & 63. & 64. & 65. & 66. & 67. & 68. & 69. & 70. & 71. & 72. \\
\hline 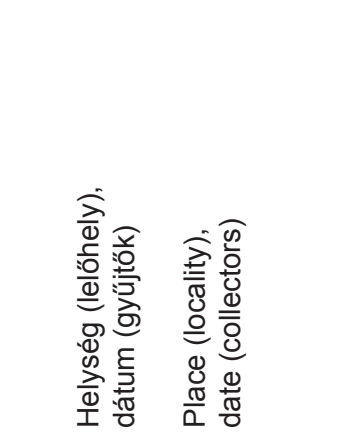 & 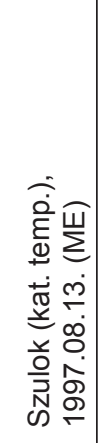 & 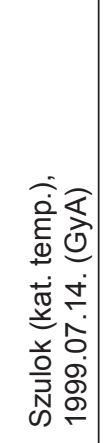 & 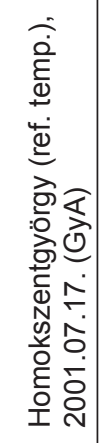 & 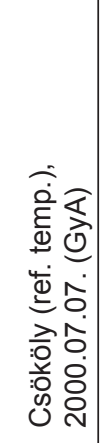 & 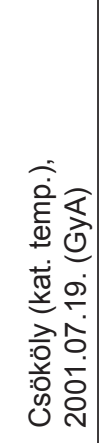 & 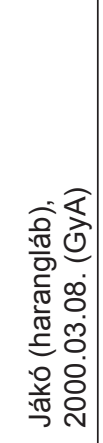 & 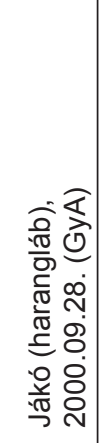 & 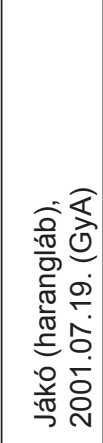 & 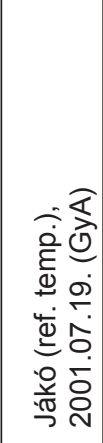 & 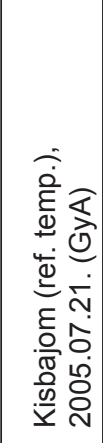 & 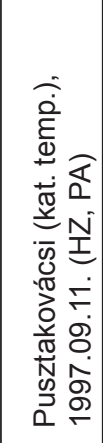 & 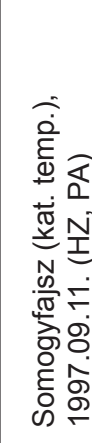 \\
\hline UTM (10x10 km) & XM90 & XM90 & XM91 & XM93 & XM93 & XM93 & XM93 & XM93 & XM93 & XM93 & XM95 & XM95 \\
\hline Crocidura leucodon & 19 & 4 & 34 & 4 & 3 & & 1 & 2 & & 21 & 14 & \\
\hline Crocidura suaveolens & 5 & 4 & 9 & 3 & 5 & 5 & 2 & 4 & & 16 & 25 & 10 \\
\hline Sorex araneus & 2 & 21 & 15 & 9 & 9 & 32 & 34 & 4 & 29 & 33 & 31 & 76 \\
\hline Sorex minutus & 1 & 3 & 4 & 1 & 2 & 7 & 11 & & 5 & 18 & 6 & 13 \\
\hline Neomys anomalus & 4 & 7 & 4 & 1 & 1 & 24 & 2 & 6 & 2 & 4 & 1 & 13 \\
\hline Neomys fodiens & & & & & 1 & & & & & & 2 & 2 \\
\hline Muscardinus avellanarius & & 1 & & 1 & & & & & 2 & & & \\
\hline Microtus agrestis & 1 & 6 & 4 & 1 & 1 & 4 & 4 & 2 & 4 & 10 & 7 & 7 \\
\hline Microtus arvalis & 15 & 22 & 37 & 5 & 6 & 17 & 14 & 16 & 8 & 66 & 54 & 38 \\
\hline Microtus subterraneus & 1 & 5 & 1 & & 4 & 3 & 1 & 3 & 3 & 5 & 1 & 7 \\
\hline Arvicola amphibius & 1 & 1 & 1 & & 1 & & & & & 1 & & 6 \\
\hline Myodes glareolus & & 3 & 1 & 1 & 2 & 6 & 1 & 4 & 2 & 9 & 4 & 2 \\
\hline Apodemus agrarius & 3 & 2 & & & 1 & 31 & 6 & 5 & 5 & 10 & 8 & 15 \\
\hline Apodemus flavicollis & & 4 & 3 & 1 & 5 & 3 & 4 & & & 10 & 3 & 5 \\
\hline Apodemus sylvaticus & 1 & & 18 & 4 & 3 & 2 & 3 & 3 & 2 & 8 & & 8 \\
\hline Apodemus uralensis & & & 1 & & & & & & & & & \\
\hline Apodemus sp. & & 2 & 3 & 2 & 2 & 3 & & 3 & 1 & 2 & 4 & 21 \\
\hline Micromys minutus & 5 & 3 & 3 & & 1 & & 2 & 1 & & 2 & 3 & 9 \\
\hline Mus musculus & & 1 & 1 & & & & 1 & & & 7 & 6 & 6 \\
\hline Mus spicilegus & & 2 & 5 & 1 & 1 & & 1 & & & 1 & 2 & 2 \\
\hline Rattus rattus & 1 & & & & & & & & & & & \\
\hline Rattus sp. & & & & & & & & 1 & & & & \\
\hline Aves (indet.) & & 1 & & 2 & 2 & 2 & & 1 & & & 2 & 10 \\
\hline Amphibia ( $P$. fuscus) & & & & & 1 & & & & 1 & & & 2 \\
\hline Zsákmány / Prey & 59 & 92 & 144 & 36 & 51 & 139 & 87 & 55 & 64 & 223 & 173 & 252 \\
\hline Köpet / Pellet & 15 & 28 & 43 & 15 & 24 & 44 & 28 & 22 & 19 & 81 & 51 & 100 \\
\hline
\end{tabular}



GYÖNGYBAGOLY KÖPETEK VIZSGÁLATA ALAPJÁN

1g. táblázat. A gyöngybagoly köpetmintákból (73-84) elökerült zsákmányállatok száma. Table 1g. Number of prey specimens in pellets of Barn Owl in samples 73-84.

\begin{tabular}{|c|c|c|c|c|c|c|c|c|c|c|c|c|}
\hline Minták / Samples & 73. & 74. & 75. & 76. & 77. & 78. & 79. & 80. & 81. & 82. & 83. & 84. \\
\hline 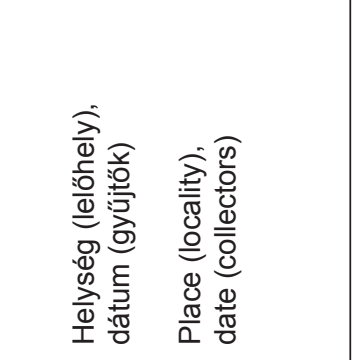 & 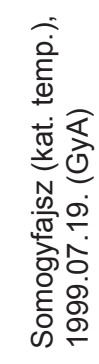 & 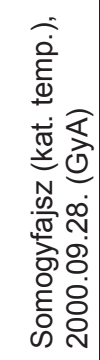 & 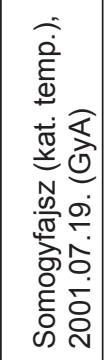 & 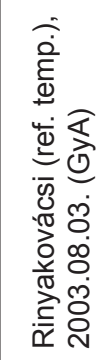 & 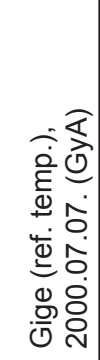 & 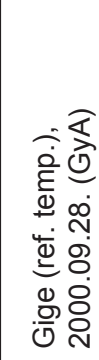 & 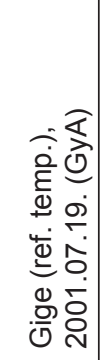 & 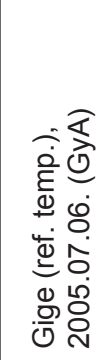 & 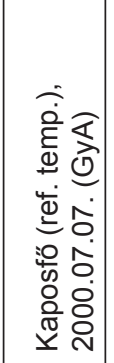 & 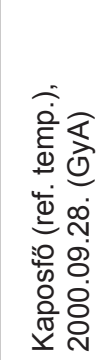 & 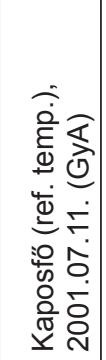 & 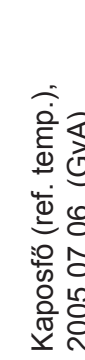 \\
\hline UTM $(10 \times 10 \mathrm{~km})$ & XM95 & XM95 & XM95 & YM02 & YM03 & YM03 & YM03 & YM03 & YM03 & YM03 & YM03 & YM03 \\
\hline Crocidura leucodon & & & 3 & 53 & 1 & 4 & 5 & 17 & & & 3 & 13 \\
\hline Crocidura suaveolens & 3 & 8 & 9 & 18 & 13 & 9 & 9 & 9 & 1 & & 3 & 13 \\
\hline Sorex araneus & 43 & 58 & 25 & 13 & 42 & 33 & 40 & 15 & 39 & 19 & 9 & 30 \\
\hline Sorex minutus & 13 & 11 & 8 & 11 & 9 & 11 & 9 & 26 & 5 & 6 & & 17 \\
\hline Neomys anomalus & 5 & 4 & 2 & 2 & 2 & 6 & 4 & 1 & 14 & 11 & 2 & 9 \\
\hline Neomys fodiens & 3 & 1 & 1 & & & & & & 2 & 1 & 3 & 2 \\
\hline Muscardinus avellanarius & & 1 & 1 & 1 & 2 & & 2 & 2 & & & & 2 \\
\hline Microtus agrestis & 16 & 3 & 5 & 11 & 2 & 4 & 14 & 7 & 6 & 7 & 9 & 13 \\
\hline Microtus arvalis & 49 & 18 & 19 & 51 & 28 & 25 & 35 & 43 & 56 & 10 & 20 & 18 \\
\hline Microtus subterraneus & 8 & 2 & 9 & 6 & 4 & 1 & 7 & 3 & 4 & 3 & 3 & 12 \\
\hline Arvicola amphibius & 2 & & 4 & 1 & & 1 & & 1 & & & & 4 \\
\hline Myodes glareolus & 4 & & 1 & 3 & 3 & 5 & 8 & 3 & 4 & 3 & 4 & 13 \\
\hline Apodemus agrarius & 24 & 6 & 5 & 5 & 25 & 16 & 20 & 5 & 10 & 5 & 4 & 20 \\
\hline Apodemus flavicollis & 5 & & 5 & 7 & 8 & 5 & 7 & 11 & 5 & 5 & 14 & 32 \\
\hline Apodemus sylvaticus & 6 & 3 & 5 & 7 & 10 & 5 & 15 & 9 & 4 & & 13 & 17 \\
\hline Apodemus sp. & 7 & 4 & 4 & 10 & 4 & 12 & 10 & 4 & & 1 & 4 & 4 \\
\hline Micromys minutus & 4 & 1 & & & 1 & & 2 & 2 & 1 & 1 & 4 & 4 \\
\hline Mus musculus & 5 & 1 & 1 & 7 & 2 & 11 & 8 & 5 & 2 & & 5 & 12 \\
\hline Mus spicilegus & & & & 1 & 2 & 2 & 7 & 3 & 1 & & 5 & 1 \\
\hline Rattus norvegicus & & & & & 1 & 2 & 1 & & & & & 9 \\
\hline Aves (indet.) & 14 & 7 & 12 & 5 & 5 & 3 & 6 & 3 & & & 1 & 3 \\
\hline Amphibia (P. fuscus) & 1 & & & 3 & & 1 & & 1 & & & & \\
\hline Amphibia (Rana sp.) & & & 1 & & 2 & & & & & & & \\
\hline Coleoptera (indet.) & 1 & & & & & & & 1 & & & & \\
\hline Zsákmány / Prey & 213 & 128 & 120 & 215 & 166 & 156 & 209 & 171 & 154 & 72 & 106 & 248 \\
\hline Köpet / Pellet & 64 & 42 & 59 & 64 & 53 & 51 & 74 & 56 & 59 & 24 & 40 & 112 \\
\hline
\end{tabular}


1h. táblázat. A gyöngybagoly köpetmintákból (85-96) előkerült zsákmányállatok száma. Table 1h. Number of prey specimens in pellets of Barn Owl in samples 85-96.

\begin{tabular}{|c|c|c|c|c|c|c|c|c|c|c|c|c|}
\hline Minták / Samples & 85. & 86. & 87. & 88. & 89. & 90. & 91. & 92. & 93. & 94. & 95. & 96. \\
\hline 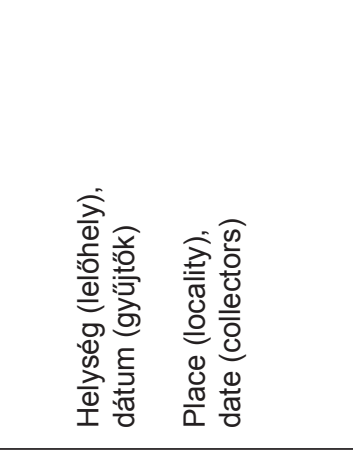 & 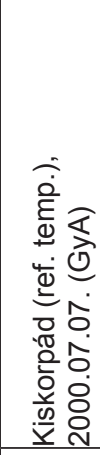 & 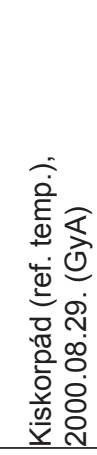 & 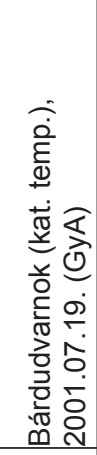 & 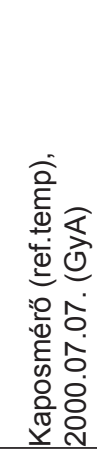 & 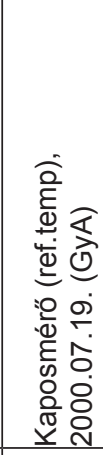 & 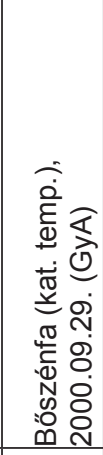 & 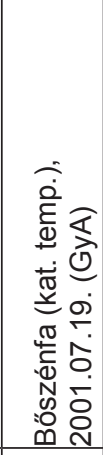 & 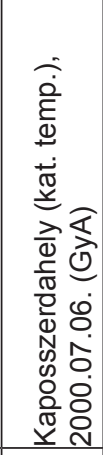 & 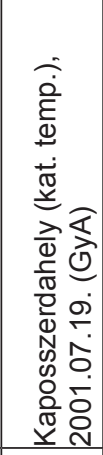 & 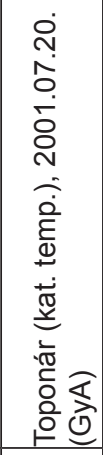 & 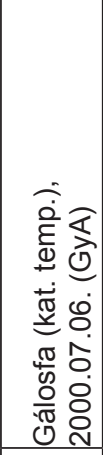 & 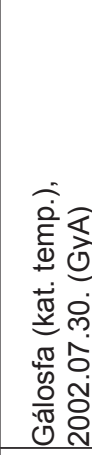 \\
\hline UTM (10x10 km) & YM03 & YM03 & YM03 & YM03 & YM03 & YM12 & YM12 & YM13 & YM13 & YM14 & YM22 & YM22 \\
\hline Crocidura leucodon & & & 4 & & & 2 & & & 2 & 1 & 2 & \\
\hline Crocidura suaveolens & 4 & 6 & 1 & 3 & 2 & 11 & 2 & 8 & 7 & & 3 & 3 \\
\hline Sorex araneus & 42 & 22 & 1 & 17 & 21 & 30 & 6 & 6 & 5 & & 4 & 1 \\
\hline Sorex minutus & 2 & 8 & & 2 & 7 & 3 & & 1 & 1 & 1 & 3 & 1 \\
\hline Neomys anomalus & 26 & 4 & 2 & 12 & 4 & 1 & & 7 & 1 & & 1 & \\
\hline Neomys fodiens & & 2 & 1 & 5 & 2 & & & & & & & \\
\hline Talpa europaea & & & & & & 1 & & 1 & & & & \\
\hline Muscardinus avellanarius & & 1 & 1 & 1 & 1 & & & & & & & \\
\hline Microtus agrestis & 3 & 12 & 3 & 13 & 3 & 2 & 2 & 5 & 7 & 1 & 1 & 2 \\
\hline Microtus arvalis & 34 & 21 & 17 & 7 & 2 & 6 & 35 & 15 & 15 & 1 & 17 & 39 \\
\hline Microtus subterraneus & 17 & 8 & 5 & 3 & 3 & 1 & 3 & 3 & 5 & 3 & & \\
\hline Arvicola amphibius & & & 1 & 1 & & 2 & 1 & & & & & 2 \\
\hline Myodes glareolus & 8 & 4 & 1 & 3 & 3 & & 1 & 1 & & 1 & & \\
\hline Apodemus agrarius & 13 & 12 & 9 & 6 & 9 & & 10 & 10 & 14 & & 2 & 3 \\
\hline Apodemus flavicollis & 4 & 2 & 18 & 5 & 2 & 8 & 12 & 27 & 8 & 1 & 2 & 14 \\
\hline Apodemus sylvaticus & 2 & 4 & 3 & 4 & 2 & 1 & 1 & 6 & 6 & & 1 & 1 \\
\hline Apodemus sp. & 5 & 7 & 10 & 3 & 1 & 5 & 5 & 6 & 2 & 1 & & 1 \\
\hline Micromys minutus & 10 & & & 2 & & & & & 1 & & & 1 \\
\hline Mus musculus & 8 & 2 & 2 & 1 & 3 & 1 & & & 1 & & & \\
\hline Mus spicilegus & 2 & & & & & 1 & & & 1 & & & 1 \\
\hline Rattus norvegicus & 2 & & & & & & & & 1 & 1 & & \\
\hline Aves (indet.) & 3 & & & 4 & & & 2 & & & & & 2 \\
\hline Amphibia (P. fuscus) & & 2 & & & & & & & & & & \\
\hline Amphibia (Rana sp.) & & 1 & & & & & & & & & & \\
\hline Zsákmány / Prey & 185 & 118 & 79 & 92 & 65 & 75 & 80 & 96 & 77 & 11 & 36 & 71 \\
\hline Köpet / Pellet & 66 & 41 & 45 & 29 & 19 & 30 & 28 & 44 & 26 & 7 & 13 & 31 \\
\hline
\end{tabular}


1i. táblázat. A gyöngybagoly köpetmintákból (97-106) előkerült zsákmányállatok száma. Table 1i. Number of prey specimens in pellets of Barn Owl in samples 97-106.

\begin{tabular}{|c|c|c|c|c|c|c|c|c|c|c|}
\hline Minták / Samples & 97. & 98. & 99. & 100. & 101. & 102. & 103. & 104. & 105. & 106. \\
\hline 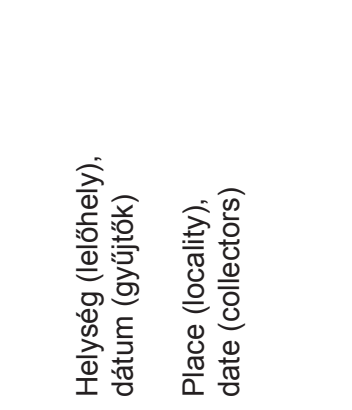 & 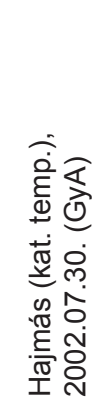 & 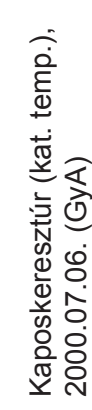 & 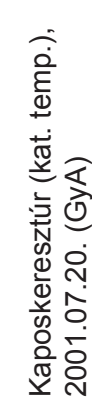 & 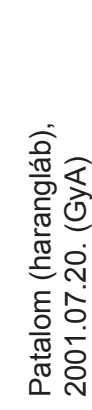 & 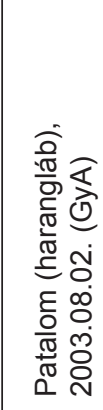 & 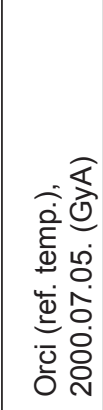 & 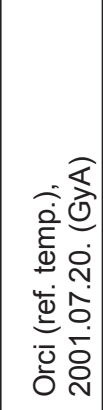 & 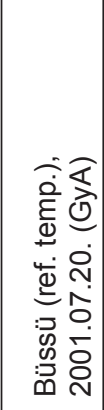 & 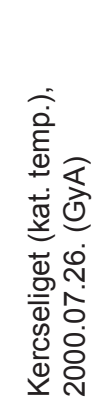 & 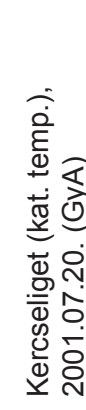 \\
\hline UTM (10x10 km) & YM22 & YM23 & YM23 & YM24 & YM24 & YM24 & YM24 & YM24 & BS73 & BS73 \\
\hline Crocidura leucodon & 35 & 7 & 1 & 1 & 5 & & & & 1 & 2 \\
\hline Crocidura suaveolens & 37 & 33 & 37 & 10 & 18 & 2 & 9 & 7 & 12 & 17 \\
\hline Sorex araneus & 11 & 22 & 17 & 13 & 89 & 17 & 133 & 15 & 9 & 5 \\
\hline Sorex minutus & 26 & 4 & 5 & 2 & 25 & 3 & 38 & 4 & 5 & \\
\hline Neomys anomalus & & 13 & 6 & 8 & 4 & 14 & 36 & 10 & 1 & \\
\hline Neomys fodiens & & & & & & & 9 & & & \\
\hline Muscardinus avellanarius & 1 & 2 & & & 1 & & 1 & & & \\
\hline Microtus agrestis & 4 & 5 & 1 & 5 & 5 & & 11 & 3 & 2 & 3 \\
\hline Microtus arvalis & 73 & 45 & 18 & 29 & 18 & 6 & 36 & 41 & 12 & 34 \\
\hline Microtus subterraneus & 5 & 13 & 15 & 8 & 7 & & 16 & 16 & 8 & 6 \\
\hline Arvicola amphibius & 1 & & 1 & 7 & & 1 & 6 & 1 & & \\
\hline Myodes glareolus & 1 & & 1 & 5 & 5 & 0 & 8 & 1 & 1 & 1 \\
\hline Apodemus agrarius & 11 & 17 & 4 & 4 & 7 & 6 & 11 & 9 & 10 & 3 \\
\hline Apodemus flavicollis & 8 & & 5 & 18 & 5 & 1 & 6 & 11 & 17 & 22 \\
\hline Apodemus sylvaticus & 4 & 3 & 10 & 12 & 7 & 2 & 8 & 4 & 9 & 10 \\
\hline Apodemus sp. & 6 & 4 & 2 & 15 & 1 & 2 & 9 & 14 & 3 & 3 \\
\hline Micromys minutus & 1 & 3 & 2 & 1 & & 1 & & & & 1 \\
\hline Mus musculus & 2 & 5 & 2 & 6 & 1 & 2 & 3 & 8 & 2 & 2 \\
\hline Mus spicilegus & 2 & 3 & 2 & 1 & & & & 1 & 2 & \\
\hline Rattus norvegicus & & 2 & 3 & & 2 & & & & & \\
\hline Aves (indet.) & 1 & 1 & 1 & 3 & 1 & 2 & 6 & & & \\
\hline \multicolumn{11}{|l|}{ Amphibia ( $P$. fuscus) } \\
\hline Amphibia (Rana sp.) & & 1 & & & & & 5 & & & \\
\hline Zsákmány / Prey & 229 & 183 & 133 & 148 & 201 & 59 & 351 & 145 & 94 & 109 \\
\hline Köpet / Pellet & 70 & 54 & 41 & 68 & 42 & 19 & 116 & 62 & 41 & 52 \\
\hline
\end{tabular}


2a. táblázat. Az emlősfajok mennyiségi megoszlása a vizsgált UTM négyzetekben ( ${ }^{*}$ édett faj, új elöfordulási adat). Table 2a. Quantitative distribution of mammal species in the investigated UTM grids (" protected species, new occurences).

\begin{tabular}{|c|c|c|c|c|c|c|c|c|c|c|}
\hline UTM (10x10 km) & XL89 & XL99 & YL08 & YL09 & XM52 & XM61 & XM62 & XM70 & XM72 & XM74 \\
\hline Crocidura leucodon* & 166 & 2 & 55 & 17 & 10 & 1 & 2 & 3 & 40 & 20 \\
\hline Crocidura suaveolens* & 114 & 10 & 256 & 52 & 19 & 17 & 16 & 9 & 14 & 14 \\
\hline Sorex araneus* & 98 & 4 & 87 & 27 & 120 & 43 & 23 & 29 & 43 & 28 \\
\hline Sorex minutus* & 57 & & 20 & 10 & 28 & 17 & 3 & 8 & 18 & 6 \\
\hline Neomys anomalus* & 61 & & 87 & 3 & 15 & 22 & 4 & 4 & 2 & \\
\hline Neomys fodiens* & 2 & & 5 & & 2 & 5 & 2 & 1 & & \\
\hline Myotis myotis* & & & & & & & & 1 & & \\
\hline Muscardinus avellanarius* & 1 & & 3 & 1 & 1 & & 1 & 1 & & \\
\hline Microtus agrestis* & 17 & & 108 & 26 & 6 & 4 & 6 & 9 & 8 & 1 \\
\hline Microtus arvalis & 133 & 53 & 531 & 437 & 101 & 38 & 68 & 44 & 44 & 26 \\
\hline Microtus subterraneus & 13 & & 12 & 6 & 2 & 2 & 9 & 2 & 4 & 6 \\
\hline Arvicola amphibius & 1 & & 8 & 9 & & & 2 & 2 & 5 & \\
\hline Myodes glareolus & 27 & 2 & 12 & 7 & 1 & & 5 & 7 & 12 & 1 \\
\hline Apodemus agrarius & 90 & 14 & 95 & 55 & 6 & 4 & 13 & 12 & 19 & 3 \\
\hline Apodemus flavicollis & 20 & 3 & 44 & 28 & 1 & & 10 & 9 & 7 & 4 \\
\hline Apodemus sylvaticus & 13 & 7 & 20 & 16 & 5 & 1 & 21 & 5 & 14 & 1 \\
\hline Apodemus sp. & 17 & & 25 & 31 & 1 & & 14 & 3 & 2 & 5 \\
\hline Micromys minutus* & 15 & & 37 & 3 & 1 & 7 & 1 & 2 & 4 & 1 \\
\hline Mus musculus & 8 & 7 & 31 & 8 & 6 & 1 & 8 & 2 & 14 & 9 \\
\hline Mus spicilegus & 4 & 3 & 11 & 4 & & & 2 & 1 & 1 & \\
\hline Mus sp. & & & 2 & & & & & & & \\
\hline Rattus norvegicus & & 9 & 2 & 16 & 1 & & & 2 & 27 & \\
\hline Rattus sp. & & 2 & 1 & & & & & 1 & 2 & \\
\hline Mustela nivalis* & 1 & & & & & & & & & \\
\hline Összesen / Total & 858 & 116 & 1452 & 756 & 326 & 162 & 210 & 157 & 280 & 125 \\
\hline
\end{tabular}


2b. táblázat. Az emlősfajok mennyiségi megoszlása a vizsgált UTM négyzetekben (*védett faj, új előfordulási adat). Table 2a. Quantitative distribution of mammal species in the investigated UTM grids ("protected species, new occurences).

\begin{tabular}{|c|c|c|c|c|c|c|c|c|c|}
\hline UTM (10x10 km) & XM80 & XM81 & XM82 & XM83 & XM84 & XM90 & XM91 & XM93 & XM95 \\
\hline Crocidura leucodon* & 179 & 44 & 18 & 3 & 1 & 118 & 34 & 31 & 17 \\
\hline Crocidura suaveolens* & 284 & 58 & 33 & 20 & 14 & 74 & 9 & 35 & 55 \\
\hline Sorex araneus ${ }^{*}$ & 359 & 141 & 30 & 87 & 31 & 30 & 15 & 150 & 233 \\
\hline Sorex minutus* & 107 & 24 & 7 & 7 & 4 & 4 & 4 & 44 & 51 \\
\hline Neomys anomalus* & 75 & 46 & 2 & 14 & 4 & 17 & 4 & 40 & 25 \\
\hline Neomys fodiens* & 11 & 6 & 2 & 1 & & & & 1 & 9 \\
\hline Talpa europaea* & 2 & & & & & & & & \\
\hline Eptesicus serotinus* & & 1 & & & & & & & \\
\hline Nyctalus leisleri* & & 1 & & & & & & & \\
\hline Nyctalus noctula* & & 1 & & & & & & & \\
\hline Myotis myotis* & & 1 & & & & & & & \\
\hline Muscardinus avellanarius* & 5 & 2 & 1 & & & 1 & & 3 & 2 \\
\hline Microtus agrestis* & 99 & 35 & 6 & 3 & 3 & 8 & 4 & 26 & 38 \\
\hline Microtus arvalis & 394 & 165 & 135 & 48 & 32 & 118 & 37 & 132 & 178 \\
\hline Microtus subterraneus & 95 & 28 & 18 & 2 & 3 & 8 & 1 & 19 & 27 \\
\hline Arvicola amphibius & 11 & 8 & & 1 & & 7 & 1 & 2 & 12 \\
\hline Myodes glareolus & 67 & 13 & 13 & & & 3 & 1 & 25 & 11 \\
\hline Apodemus agrarius & 191 & 39 & 14 & 3 & 5 & 40 & & 58 & 58 \\
\hline Apodemus flavicollis & 66 & 34 & 10 & & 1 & 11 & 3 & 23 & 18 \\
\hline Apodemus sylvaticus & 46 & 32 & 23 & 3 & 5 & 10 & 18 & 25 & 22 \\
\hline Apodemus uralensis & & & & & & & 1 & & \\
\hline Apodemus sp. & 49 & 30 & 6 & & 2 & 12 & 3 & 13 & 40 \\
\hline Micromys minutus* & 22 & 2 & 3 & & 2 & 15 & 3 & 6 & 17 \\
\hline Mus musculus & 42 & 8 & 5 & 2 & 3 & 2 & 1 & 8 & 19 \\
\hline Mus spicilegus & 15 & 15 & 5 & 1 & 3 & 12 & 5 & 4 & 4 \\
\hline Mus sp. & & & & & & 1 & & & \\
\hline Rattus norvegicus & 29 & & & & & & & & \\
\hline Rattus rattus & & & & & & 1 & & & \\
\hline Rattus sp. & 8 & & & & & & & 1 & \\
\hline Összesen / Total & 2156 & 734 & 331 & 195 & 113 & 492 & 144 & 646 & 836 \\
\hline
\end{tabular}


2c. táblázat. Az emlösfajok mennyiségi megoszlása a vizsgált UTM négyzetekben ('védett faj, új előfordulási adat). Table $2 b$. Quantitative distribution of mammal species in the investigated UTM grids (" protected species, new occurences).

\begin{tabular}{|l|r|r|r|r|r|r|r|r|r|}
\hline UTM (10x10 km) $^{\text {YM02 }}$ & YM03 & YM12 & YM13 & YM14 & YM22 & YM23 & YM24 & BS73 \\
\hline Crocidura leucodon* $^{*}$ & 53 & 47 & 2 & 2 & 1 & 37 & 8 & 6 & 3 \\
\hline Crocidura suaveolens* $^{*}$ & 18 & 73 & 13 & 15 & & 43 & 70 & 46 & 29 \\
\hline Sorex araneus* & 13 & 330 & 36 & 11 & & 16 & 39 & 267 & 14 \\
\hline Sorex minutus* & 11 & 102 & 3 & 2 & 1 & 30 & 9 & 72 & 5 \\
\hline Neomys anomalus* $^{*}$ & 2 & 97 & 1 & 8 & & 1 & 19 & 72 & 1 \\
\hline Neomys fodiens* & & 18 & & & & & & 9 & \\
\hline Talpa europaea* & & & 1 & 1 & & & & & \\
\hline Muscardinus avellanarius* & 1 & 12 & & & & 1 & 2 & 2 & \\
\hline Microtus agrestis* & 11 & 96 & 4 & 12 & 1 & 7 & 6 & 24 & 5 \\
\hline Microtus arvalis & 51 & 316 & 41 & 30 & 1 & 129 & 63 & 130 & 46 \\
\hline Microtus subterraneus & 6 & 73 & 4 & 8 & 3 & 5 & 28 & 47 & 14 \\
\hline Arvicola amphibius & 1 & 8 & 3 & & & 3 & 1 & 15 & \\
\hline Myodes glareolus & 3 & 62 & 1 & 1 & 1 & 1 & 1 & 19 & 2 \\
\hline Apodemus agrarius & 5 & 154 & 10 & 24 & & 16 & 21 & 37 & 13 \\
\hline Apodemus flavicollis & 7 & 118 & 20 & 35 & 1 & 24 & 5 & 41 & 39 \\
\hline Apodemus sylvaticus & 7 & 88 & 2 & 12 & & 6 & 13 & 33 & 19 \\
\hline Apodemus sp. & 10 & 65 & 10 & 8 & 1 & 7 & 6 & 41 & 6 \\
\hline Micromys minutus* & & 27 & & 1 & & 2 & 5 & 2 & 1 \\
\hline Mus musculus & 7 & 61 & 1 & 1 & & 2 & 7 & 20 & 4 \\
\hline Mus spicilegus & 1 & 23 & 1 & 1 & & 3 & 5 & 2 & 2 \\
\hline Rattus norvegicus & 15 & & 1 & 1 & & 5 & 2 & \\
\hline Összesen / Total & & 1785 & 153 & 173 & 11 & 333 & 313 & 887 & 203 \\
\hline
\end{tabular}




\title{
Date to the knowledge of small mammal fauna of Somogy county (Hungary), based on Barn Owl Tyto alba (ScOPOLI, 1769) pellet analysis
}

\author{
JENÖ J. PURGER
}

\begin{abstract}
Barn Owl pellets collected in Somogy county were analysed, with the purpose of contributing to the knowledge about small mammal fauna of the county with new data. Pellets were collected between 1995 and 2016, from 53 localities (investigated areas: XL89, XL99, YL08, YL09, XM52, XM61, XM62, XM70, XM72, XM74, XM80, XM81, XM82, XM83, XM84, XM90, XM91, XM93, XM95, YM02, YM03, YM12, YM13, YM14, YM22, YM23, YM24 and BS73, according to $10 \times 10 \mathrm{~km}$ UTM grids). In a total of 5164 Barn Owl pellets 14360 prey remnants were found (2.8 was the prey per pellet ratio). In the diet of Barn Owls small mammals dominated $(98.6 \%)$, while the remnants of birds, amphibians and insects made up $1.4 \%$ of total prey. Distribution data for 27 small mammal species (from this 15 protected species *) are presented. Mammal
\end{abstract}

prey consisted of Soricomorpha $42.3 \%$ (Crocidura leucodon*, C. suaveolens*, Sorex araneus*, S. minutus*, Neomys anomalus*, N. fodiens*, Talpa europaea*), Chiroptera $0.03 \%$ (Eptesicus serotinus*, Nyctalus leisleri*, N. noctula*, Myotis myotis*) and Rodentia 57.6\% (Muscardinus avellanarius* ${ }^{*}$ Microtus agrestis*, M. arvalis, M. subterraneus, Arvicola amphibius, Myodes glareolus, Apodemus agrarius, A. flavicollis, A. sylvaticus, A. uralensis, Micromys minutus*, Mus musculus, $M$. spicilegus, Rattus norvegicus, $R$. rattus), but the remnants of one Weasel Mustela nivalis* (Carnivora) were also found in the owl pellets. The majority of these data confirm our earlier knowledge about the distribution of particular species, but in the case of 9 small mammal species, new occurrence data are provided. 
